\author{
Matgorzata A. Szyszkowska \\ Uniwersytet Muzyczny F. Chopina w Warszawie \\ ORCID 0000-0003-1783-256X
}

\title{
Wolność, nieskończoność, wzniosłość: przestrzeń duchowa w doświadczaniu muzyki religijnej w perspektywie fenomenologicznej ${ }^{1}$
}

\begin{abstract}
...mówię o sztuce bardziej świętej, o tej, która, jak powiadali starożytni, jest narzędziem bogów, zwiastunką boskich tajemnic, wyjawicielką idei, mówię o nieziemskim pięknie, którego czysty płomień rozświeca tylko nieskalane dusze i którego postać jest oku zmysłów równie niedostępna i zakryta jak kształt prawdy².
\end{abstract}

Pojęcia abstrakcyjne (idee), mówi William James, wyznaczają pewien kierunek myślenia i działania. Kierunek, który nie musi być jednoznaczny ani ściśle określony, ale który wiąże się z doświadczeniami, przekonaniami oraz wartościami.

\begin{abstract}
Abstrakcje polaryzują i magnetyzują nas: zwracamy się ku nim lub odwracamy się od nich, szukamy ich, dzierżymy je, nienawidzimy lub błogosławimy je akurat tak samo, jak gdyby to były istoty konkretne ${ }^{3}$.
\end{abstract}

W kontekście tych ostatnich - zwłaszcza doświadczeń i wartości - ów kierunek myślenia wyznacza coś, co można także nazwać przestrzenią duchowości. W odwołaniu do doświadczeń religijnych, ale także doświadczeń muzyki religijnej, można mówić o szczególnego rodzaju aktywności otwierania lub inaczej kreowania przestrzeni duchowej, rozumianej jako symbolicznie wyznaczony obszar, na który składają się zarówno samo doznawanie, jak i świadomość, i interpretacja doznań związanych z egzystencją. Max Scheler mówi w tym wypadku po prostu

1 Praca powstała w trakcie realizacji projektu nr 2016/23/B/HS1/02325 finansowanego przez Narodowe Centrum Nauki.

2 F. W. J. Schelling, Filozofia sztuki, przeł. K. Krzemieniowa, Warszawa 1983, s. 7.

3 W. James, Doświadczenia religijne, przeł. J. Hempel, Warszawa 1958, s. 54. 
o „duchowym ja” ${ }^{4}$. Inni autorzy określają to jeszcze ogólniej mianem duchowości. Jednak posłużenie się terminem „przestrzeń duchowa” pozwala na odwołanie się do stanów wyraźniejszych, ale i dłuższych, do doświadczeń i ich konsekwencji, do wartości i procesów wartościowania, a wreszcie do przeświadczeń i obrazów, które się z nimi łączą. Przestrzeń duchowa w rozumieniu, które tu proponuję, może, choć nie musi, odnosić się do sfery niewidzialnej i niewyrażalnej, jako do elementu lub przyczyny owych doświadczeń. W sferze religijnej, jak pisze James, doświadczenie duchowe, religijne lub mistyczne, będzie nie tylko związane ze sferą symboliczną czy sferą wartości, ale będzie także sposobem życia. Nawiązując do Jamesa, chciałabym doświadczenia duchowe związane ze słuchaniem muzyki religijnej traktować dalej jako doświadczenia wykraczające poza praktykę i empiryczne doświadczenie. Przestrzeń duchowa, wyznaczona myśleniem wykraczającym poza praktyczne potrzeby i cele, bywa indukowana w szczególny sposób przez muzykę. Chciałabym wskazać na doświadczenia muzyczne, w tym zwłaszcza na doświadczenia muzyki religijnej, jako na doświadczenia, które otwierają wewnętrzną przestrzeń duchową i oferują słuchaczom niezwykłe przeżycia duchowe. Muzyka religijna tworzona jest współcześnie przez kompozytów nie tylko w oparciu o teksty liturgiczne lub nawiązujące do konkretnej okazji religijnej, ale powstaje często z zamysłem umożliwienia kontemplacji czy skłonienia do metafizycznego namysłu. W związku z tym mówiąc o muzyce religijnej, będę miała na myśli również kompozycje niezwiązane z liturgią czy obrządkiem wyznaniowym ${ }^{5}$.

Dla wielu odbiorców muzyki doświadczenie estetyczne dzieła muzycznego, wykonania czy nagrania muzycznego nie kończy się i nie opiera wyłącznie na wysłuchaniu kompozycji dźwiękowej, ale wraz z tym doświadczeniem staje się przejściem do innego świata, wkroczeniem w przestrzeń samopoznania, a także przekroczeniem własnej podmiotowości na rzecz transcendencji, wolności, nieskończoności.

W dalszym ciągu pracy chciałabym zastanowić się nad rolą muzyki, która uczestniczy w tym doświadczeniu, a szczególnie muzyki religijnej, w kształtowaniu owego szeroko rozumianego doświadczenia oraz otwieraniu przestrzeni duchowej. Chciałabym zwrócić uwagę na podobieństwa doświadczeń religijnych w ich szeroko pojętym duchowym aspekcie do doświadczeń estetycznych. Być może, jak mówił Karol Wojtyła, „piękno jest kluczem tajemnicy i wezwaniem transcendencji, a także budzi ową utajoną tęsknotę za Bogiem" ${ }^{6}$.

4 M. Scheler, Istota i formy sympatii, przeł. A. Węgrzecki, Warszawa 1980, s. 327.

5 Por. S. Dąbek, Wspótczesna muzyka religijna. Uwarunkowania i aspekt duchowy, „Ethos” 19 (2006) nr 1-2, s. 77-78.

6 W. Stróżewski, Wokót piękna. Szkice z estetyki, Kraków 2002, s. 167. 


\section{Nieskończoność}

Stanisław Dąbek, pisząc o muzyce religijnej, proponuje rozszerzenie używanej terminologii, mając na względzie społeczne oraz kulturowe zmiany prowadzące do rozluźnienia związków muzyki tworzonej przez kompozytorów profesjonalnych z diasporą religijną. W tym kontekście Dąbek mówi o muzyce religijnie inspirowanej $^{7}$. Przyjmując to jako istotną uwagę, pozostaję jednak przy ogólnym określeniu doświadczenia muzyki religijnej, nie precyzując bliżej intencji kompozytorskiej, o ile inne elementy muzyczne, tj. np. tekst lub tytuł utworu, wskazują na jego możliwe związki, jeśli nawet nie z funkcją religijną, to z doświadczeniem. W tym kontekście istotny wydaje się komentarz Mirosława Perza, który zwracał uwagę na przeformułowanie samego sensu muzyki poprzez dodanie do niej „elementu” sacrum $^{8}$. Ambiwalencję samego określenia muzyki sakralnej muzykolog podkreślał, powołując się zarówno na historię, jak i na współczesną praktykę.

Moim przewodnikiem pozostaje jednak James, który opisując postawę religijną oraz religijne doświadczenie, zwraca uwagę na podstawowe wyznaczniki, które dają się sprowadzić do określonego światopoglądu. Postawa religijna zakłada więc, w najbardziej ogólnym sensie, uznanie istnienia ponadzmysłowej, niewidzialnej i niewyrażalnej sfery; i dalej zakłada również, że szczęście i dobro ludzkie zależy od dostosowania się i zharmonizowania z tą sferą̧

Jeśliby zażądano, abyśmy scharakteryzowali życie religijne w sposób jak najogólniejszy, moglibyśmy powiedzieć, że polega ono na wierze w porządek wyższy, niewidzialny, i w to, że najwyższe nasze dobro zależne jest od naszego dostrojenia się do tego porządku. Ta wiara i to dostrojenie się są właśnie religijną postawą duszy ${ }^{10}$.

W ten uproszczony sposób James przedstawia podstawowy element wiary religijnej, która odwołuje się do tego, co nie tylko przekracza rozum czy empiryczne potoczne doświadczenie, ale zakłada konieczność uznania tej niewidzialnej rzeczywistości za podstawową i niepodważalną. Biorąc to pod uwagę, należałoby określać muzykę mianem religijnej nie wyłącznie ze względu na pełnioną funkcję

7 Zob. S. Dąbek, Wspótczesna muzyka religijna. Uwarunkowania i aspekt duchowy, dz. cyt., s. 78.

8 Zob. M. Perz, Interpretacje muzycznego „sacrum” w kontekście polskiej tradycji, w: Wspótczesna polska religijna kultura muzyczna jako przedmiot badań muzykologii, pod red. B. Bartkowskiego, S. Dąbka, A. Zoły, Lublin 1992, s. 23.

9 Zob. W. James, Doświadczenia religijne, dz. cyt., s. 51.

10 W. James, Doświadczenia religijne, dz. cyt., s. 51. 
liturgiczną ani wyznanie kompozytora, ale raczej ze względu na założenie i odnoszenie się do sfery niewidzialnej. Takie potraktowanie tematu powoduje jednak dużą trudność w odnoszeniu się do muzyki, w której intencja kompozytorska pozostaje zupełnie niejasna i która nie posiada czytelnego tekstu. Być może jednak, jak pisze Scheler, ta obawa jest zupełnie zbyteczna i postępując zgodnie z metodą fenomenologiczną, natrafiamy na świat duchowy, którego materialne przejawy pozostają niewspółmierne wobec doświadczeń, ku którym prowadzą.

Doświadczenie muzyki związane jest z perspektywą nieskończoności dzięki funkcjom religijnym, tradycyjnie pełnionym przez muzykę. Msza, kantata, pieśń religijna ze względu na swój związek z liturgią kościelną lub rytuałem religijnym otwierają odbiorcę na to, co pozostaje ponad codziennością i praktycznym doznaniem w sposób bardziej jeszcze wyraźny niż pozostałe doświadczenia estetyczne. Ze względu na charakter doświadczenia religijnego, które odwołuje się do tego, co niewidzialne, do abstrakcji, do bytów duchowych, muzyka religijna zyskuje szczególny charakter. Jednak owa funkcja liturgiczna ustępuje współcześnie miejsca muzyce, która przekracza wymiar religii instytucjonalnej, jak choćby muzyka ekumeniczna, tworzona dla wyznawców wielu różnych religii. Sięga ona, w zamierzeniu kompozytora, ku temu, co niewidzialne, przygotowując doświadczenie duchowe dla swoich słuchaczy. „Otwiera ona przestrzeń duchową” poprzez wykorzystanie dźwięku, przestrzeni zastanej i wreszcie poprzez kreowanie przestrzeni duchowej, przez co mam na myśli zarówno możliwość uczestniczenia w doświadczeniu wspólnotowym, jak i możliwość indywidualnego przeżycia religijnego. Przestrzeń duchowa, którą otwiera doświadczenie muzyki religijnej, staje się przestrzenią indywidualnego rozwijania się, rozszerzania świadomości, przestrzenią przemiany.

Jednym z przykładów, do których chciałabym się odwołać, aby przybliżyć sugerowane znaczenie „kreowania przestrzeni” w sensie nie tylko symbolicznym, jest muzyka amerykańskiego kompozytora Erica Whitacre’a, która mogłaby być traktowana jako narzędzie dla uzyskania doświadczenia religijnego ${ }^{11}$. Kompozycje Whitacre'a rzadko wykorzystują teksty liturgiczne. Nie pełnią one również funkcji obrzędowych. Jednak dzięki swojej dynamice oraz szczególnemu charakterowi, w tym szczególnie dzięki wykorzystywaniu bliskich interwałów, wzbudzających harmonicznie wydawane dźwięki prowadzi do powstania kolejnej warstwy dźwiękowej i kreuje szczególną przestrzeń. Alleluja na chór mieszany $(2011)^{12}$ lub

\footnotetext{
11 Na temat muzyki Whitacre'a zob. https:/www.pri.org/stories/2019-07-18/eric-whitacres-virtual-choir (10.07.2020) oraz http://journal.juilliard.edu/journal/1402/eric-whitacre (10.07.2020).

12 Kompozytor opisuje powstanie kompozycji na swojej stronie: „After spending the $2010 \mathrm{Mi}$ chaelmas term in Cambridge (Sidney Sussex College), though, singing with dr David Skin-
} 
Sleep na chór mieszany (2010) tworzą specyficzną dźwiękową przestrzeń, która może przyczynić się do doświadczenia uczestniczenia lub duchowego otwarcia. Podobny efekt muzyczny znajdujemy w muzyce György'ego Ligetiego, którego Lux Aeterna (1966) stanowi o wiele wyraźniejszy, bardziej dynamiczny i zdecydowany przykład tego zjawiska. Jednak mocniejszy i bardziej agresywny charakter kompozycji wywoływać może zupełnie inne wrażenie. Technika, której używa Ligeti, określana przez kompozytora jako mikropolifonia lub mikrotonalność, wykorzystuje interwały dysonujące, które dynamizują i przyspieszają doświadczenie. O ile jednak w tych konkretnych przykładach, do których można by dodać również np. muzykę alikwotową czy burdonową, elementem doświadczenia staje się spontaniczne powstająca przestrzeń fizyczna, o tyle w doświadczeniu muzyki religijnej ważna jest przestrzeń symboliczna, która może lecz nie musi opierać się na dodatkowej warstwie dźwiękowej, emitowanym cieple lub przepływie energii.

W Rzeczywistych obecnościach George Steiner mówi o nieskończoności, jako o perspektywie, którą niesie ze sobą doświadczenie sztuki. Perspektywa nieskończoności w sztuce i estetyce wynika z ontycznej niekonieczności tej sfery czy też, mówiąc inaczej, z naddatku bytu, jakim jest każde dzieło. Jest ono „fenomenem wolności. Może być albo nie byc'” ${ }^{13}$. Zgodnie z definicją Arystotelesa twórczość w znaczeniu artystycznym uzupełnia przyrodę, a zatem do konieczności dodaje niekonieczność, wolny i nieprzewidywalny element. W tym sensie wszystko, co wiąże się ze sztuką, przekracza zarówno konieczność przyrodniczą, jak i jej wymiar czasowy. Powstaje we własnym czasie i realizuje własny czas. Dzieło otwiera się na nieskończoność także w innym sensie: poprzez odwołanie do „cudu” twórczości, a także zarysowanie możliwego, choć nieokreślonego bliżej spełnienia. Dzieło sztuki jest niewyczerpywalne nie dlatego, że nie jest gotowe lub nie jest dokończone, ale dlatego, że wykracza poza każdy koniec i każdą gotowość, tak jak wykracza poza tu i teraz aktualnego wykonania i doświadczania. W tym sensie jest zawsze obietnica, nadzieją, wizją przyszłości; wykraczając poza to, co jest (przedmiot), wskazuje na to, co być może (doświadczenie). Odnosi się do innego świata, innej logiki, innej prawdy. Choć jest zrealizowaną możliwością, ta realizacja nigdy nie jest ostateczna; sam fakt dzieła wskazuje na dzieło jako na możliwość. Dzieło sztuki, przypomina Steiner, otwiera odbiorców na pozaempiryczny świat, na doznanie - przyjemności, spełnienia, natchnienia, a także na idee: doskonałości,

ner and his marvelous Chapel Choir, I began to see the deep wisdom in the liturgical service. I found myself suddenly open to the history and the beauty of the poetry, and it was the single word Alleluia, 'praise God', that most enchanted me" (https://ericwhitacre.com/ (10.06.2020)).

13 G. Steiner, Rzeczywiste obecności, przeł. O. Kubińska, Gdańsk 1997, s. 116. 
oryginalności, piękna, cudowności, wzniosłości, wolności ${ }^{14}$. Perspektywa nieskończoności jest również istotnym elementem doświadczenia religijnego według Jamesa. To, co nieskończone i niewidzialne - sfera pozadoświadczalna - stanowi podstawowy punkt odniesienia w religii. To tam kieruje się uwaga wiernych, to stamtąd oczekują oni wsparcia i odnowienia. To tam wreszcie tkwi źródło ich życia oraz nadzieja dla ich przyszłości w życiu i poza nim. Perspektywa wieczności, nieśmiertelności i nieskończoności otwiera się również przed słuchaczem muzyki religijnej. Jest symbolicznie obecna w doświadczeniu muzyki poprzez kreowaną przez nią przestrzeń, poprzez odwołanie do treści religijnych lub przez oderwanie się od własnej osoby. Muzyka, która, jak można powiedzieć, sama wznosi się ponad to, co subiektywne i jednostkowe, ku temu, co społeczne lub ogólnoludzkie, jeszcze lepiej reprezentuje i odwołuje się do szczególnie rozumianej duchowości, którą cechuje otwartość wobec innego, zmierzanie na spotkanie z innym ${ }^{15}$. Doświadczenie muzyki religijnej jest, podobnie jak sama religia, również formą komunikacji. Muzyka religijna doświadczana w czasie koncertu lub podczas ceremonii religijnej jest zawsze doświadczeniem duchowości, choćby przez to, że wykracza poza ramy jakiejkolwiek religii czy wyznania przez sam fakt zmierzania ku transcendencji. Jak mówi Scheler „«człowiek» jest intencją i gestem samej transcendencji”, ale również „... to nie człowiek się modli [ale] j e st on modlitwą życia wychodzącą ponad nie samo" ${ }^{16}$. Według Schelera miłość i duch, jakie realizują się w doświadczeniu religijnym, w religii lub w jakiejkolwiek formie oddania/ poszukiwania Boga, stanowią jedyne usprawiedliwienie intelektu człowieka. Podążając tym tropem, można powiedzieć, że sam wysiłek słuchania, uczestniczenie w doświadczeniu muzyki religijnej zarazem otwierają przed słuchaczem przestrzeń ducha, przestrzeń wolności, jak i w jakimś sensie usprawiedliwiają jego istnienie istnienie człowieka jako gatunku.

\section{Wzniosłość}

O muzyce religijnej można powiedzieć, że jest wzniosła. Kategoria wzniosłości odnoszona była do stylu wysokiego i podniosłego, i określana, jako „zdolność porywania i podnoszenia ducha" ${ }^{17}$. Była ona także łączona, jak mówi Tatarkiewicz,

14 Zob. G. Steiner, Rzeczywiste obecności, dz. cyt., s. 116.

15 Por. G. Steiner, Rzeczywiste obecności, dz. cyt., s. 114-115.

16 Podkreślenie w tekście - autor. M. Scheler, Pisma z antropologii filozoficznej i teorii wiedzy, przeł. S. Czerwniak, A. Węgrzecki, Warszawa 1987, s. 25.

17 W. Tatarkiewicz, Dzieje sześciu pojęć, Warszawa 2008, s. 200. 
„Z wielkością myśli” i „głębokością uczuć”" ${ }^{18}$. Słuchacze spodziewają się wzniosłej muzyki religijnej. I w tym kontekście można by zasugerować, że wzniosłość, o której tutaj mówimy, może być albo zamierzona przez kompozytora, albo osiągana przez wykonawcę. Słuchacz, przychodząc na koncert muzyki religijnej, spodziewa się, że muzyka ta będzie wzniosła, niezwykła, a może nawet przekraczająca wszystko, czego do tej pory słuchał. Ale może być również i tak, że bez względu na oczekiwania własne, słuchacz podda się działaniu muzyki, która okaże się dla niego zbyt wielka, zbyt nieoczekiwana, pełna kontrastów i przekraczająca jego wyobrażenia w taki sposób, który kieruje ku doznaniu wzniosłości. Nowoczesne ujęcia wzniosłości przeciwstawiają wzniosłość kategorii piękna, podkreślając, że opiera się ona na wrażeniach z gruntu negatywnych i trudnych do opisania ${ }^{19}$. Wzniosłość kojarzona jest z jednej strony z zaparciem się tradycyjnego piękna, a z drugiej z potrzebą i dążeniem do nowych, niezwykłych doświadczeń, wymagając gotowości na przyjęcie zupełnie nieznanych form, jakości czy aspektów rzeczy ${ }^{20}$. W obszarze muzyki wzniosłość stała się kategorią z wyboru w sytuacji wykształcenia się nowych dużych form instrumentalnych; wydawała się być kategorią odpowiedniejszą niż tradycyjne piękno, często widziane przez pryzmat kanonu, zwłaszcza w odniesieniu do modernizmu w sztuce ${ }^{21}$. Muzyka instrumentalna od XVII wieku była wzniosła w oczach teoretyków i krytyków muzyki, choć samo rozumienie wzniosłości było dalece niejednorodne, jak wskazuje Carl Dahlhaus ${ }^{22}$. Przynajmniej częściowo wynikało to z odejścia od ideałów poprzednich epok.

Wzniosłość muzyki religijnej jest innej jeszcze natury. Dosłownie wznosi słuchaczy do góry, odrywa ich od ziemi i tego, co zmysłowe, proste i codzienne, nie jest więc ani wzniosłością kantowską, ani wzniosłością odzyskaną dla sztuki przez Theodora Adorna i Jeana-Françoisa Lyotarda, jest raczej wzniosłością w sensie bliskim starożytnemu. Można powiedzieć, że muzyka religijna bywa wzniosła w sposób bliższy starożytnej wzniosłości ${ }^{23}$. Jej wzniosłość jest wzniosłością stylu; była to także wzniosłość wynikająca z dążenia do doskonałości, zachowywania podniosłego charakteru całości. Wzniosłość muzyki religijnej przenosi się na słuchaczy, dosięga ich i porywa ze sobą. Cenny jest tutaj jeszcze inny aspekt wzniosłości, na który zwracał uwagę w swoim omówieniu Lyotard - aspekt etyczny.

18 W. Tatarkiewicz, Dzieje sześciu pojęć, dz. cyt., s. 200.

19 I. Kant, Krytyka wtadzy sądzenia, przeł. J. Gałecki, Warszawa 2004, s. 132-133.

20 Por. J. F. Lyotard, Po wzniostości: stanowisko estetyki, „Teksty Drugie” 1998 nr 4, s. 135.

21 „Od początku naszego wieku sztuka nie ma już do czynienia z pięknem, lecz z czymś, co nazwać można wzniosłością” (J. F. Lyotard, Po wzniostości: stanowisko estetyki, dz. cyt., s. 131).

22 C. Dahlhaus, Idea muzyki absolutnej i inne studia, przeł. A. Buchner, Kraków 1988, s. 67-68.

23 W. Tatarkiewicz, Dzieje sześciu pojęć, dz. cyt., s. 199. 
To, co przede wszystkim zwróciło uwagę Kanta w uczuciu wzniosłości, zawiera się w spostrzeżeniu, że stanowi ona estetyczny (negatywny) znak transcendencji odpowiadającej raczej etyce - transcendencji prawa moralnego i wolności ${ }^{24}$.

Dla Lyotarda wartość etycznej odpowiedzialności to np. dbałość o to, co małe, o najmniejszy szczegół; to świadomość i dbałość o zachowanie różnorodności. Francuski filozof, który najwięcej uwagi poświecił kategorii wzniosłości w odniesieniu do sztuki awangardowej, mówi o niuansie, jako o tym, co stanowi residuum wzniosłości; co nie poddaje się określeniu, kategoryzacji - brzmienie dźwięku, barwa ${ }^{25}$.

Wracając do określenia wzniosłości w doświadczeniu muzyki religijnej, możemy zauważyć, że słuchacze tej muzyki są często „porwani” i „włączeni” w przestrzeń, jaką tworzy ona wokół siebie. W przypadku muzyki dawnej, np. muzyki kościelnej okresu wczesnego średniowiecza, chorał gregoriański lub średniowieczne sekwencje tworzą one wokół [słuchacza] drgającą przestrzeń. Jest to przestrzeń rozchodzenia się dźwięku, ale także przestrzeń emocjonalnego oddziaływania, ciepło i atmosfera opiekuńczości ${ }^{26}$. Chorał uważany jest za mający wybitnie pozytywny wpływ na odbiorcę. Słuchacz zostaje napetniony dźwiękiem, poddaje się energii, wtapia w brzmienie całości wydarzającej się wokół niego. W sensie fizjologicznym jego ciało współgra z drganiami, których doznaje. W sensie pozafizjologicznym jego myśli i uwaga rozpraszają się w dźwiękach, w których on sam zanika. Przestaje postrzegać siebie jako centrum; doznaje, być może, czegoś w rodzaju całkowitego zapomnienia i rozproszenia, do którego dążą techniki medytacji. Wzniosłość w innym sensie wiąże się raczej ze wstrząsem; poruszeniem, które jest zarazem negatywne - Kant mówił o chwilowym zatrzymaniu sił życiowych - jak i pozytywne. Słuchacz traci na moment poczucie własnego ,ja”, poddając się działaniu dźwięków; ale jednocześnie staje się jednym z muzyką. Adorno pisał o tym, odnosząc się do modernistycznej muzyki jako źródła doznania wstrząsu [estetycznego] ${ }^{27}$. W trakcie doświadczenia „wstrząs porywa zdystansowany podmiot z powrotem do siebie” 28 .

W doświadczeniu muzyki religijnej zapomnienie o sobie i podporządkowanie doznaniu, a także emocjonalne zanurzenie jest niewątpliwie ogromne, ale w odróżnieniu od doświadczenia muzyki modernistycznej lub awangardowej, które

\footnotetext{
24 J. F. Lyotard, Po wzniostości: stanowisko estetyki, dz. cyt., s. 133.

25 Zob. J. F. Lyotard, Po wzniostości: stanowisko estetyki, dz. cyt., s. 135.

26 Por. uwagi Schmitza na temat rozszerzania się ciepła podczas wspólnego śpiewu: H. Schmitz, Ciatosfera, przestrzeń i uczucia, przekł. B. Andrzejewski, Poznań 2001, s. 25-26.

27 Zob. T. W. Adorno, Teoria estetyczna, przeł. K. Krzemień-Ojak, Warszawa 1993, s. 444.

28 T. W. Adorno, Teoria estetyczna, dz. cyt., s. 489.
} 
opisywał Adorno, zapomnienie o sobie wiąże się tutaj, o ile możemy wierzyć Jamesowi, właściwie zawsze z radosnym uniesieniem i szczęśliwością, jaka towarzyszy religijnemu wzruszeniu ${ }^{29}$. Nawet wówczas, gdy podmiot słuchający traktuje doświadczenie muzyki przede wszystkim jako element rytuału, samo doświadczenie religijne ma zawsze zdecydowanie indywidualny i emocjonalny, a także przepełniony radosnym wzruszeniem charakter ${ }^{30}$.

Steiner pisze, że doświadczenia religijne, estetyczne i metafizyczne stanowią najbardziej pochłaniające i „przeobrażające” wezwania „dostępne ludzkiemu doświadczeniu”31. Do czego jest to wezwanie? - chciałoby się zapytać. Do przemiany, być może, do odkrycia siebie, lub do podążania za tym, co idealne. Właśnie ów emocjonalny, pogodny (entuzjastyczny, powie James) charakter, podobnie jak nastawienie na przemianę, wydają się dominować w odbiorze muzyki religijnej, a także w innym sensie w doświadczeniu duchowości, jakiego dostarcza muzyka. W trakcie słuchania utworów muzycznych, które mają charakter mistyczny, religijny i które charakteryzuje wytwarzanie duchowej przestrzeni emocji i wspólnotowego doznania, indywidualność i egotyzm słuchacza ulegają osłabieniu, pozwalając mu czuć się przede wszystkim częścią wspólnoty. O ile jednak otwarcie przestrzeni wspólnotowej i samo doświadczenie duchowości można widzieć jako przedłużenie doświadczenia estetycznego, o tyle owa potrzeba przemiany i ujawnienia tego, co wewnątrz, tego, co istotowe, choć rodzi się często z doświadczenia muzyki religijnej, musi wynikać z nastawienia odbiorcy i jego własnej, indywidualnej potrzeby religijnej.

\section{Przestrzeń duchowości}

Z pewnością doświadczenie muzyki niesie ze sobą szczególny rodzaj piękna. Schelling mówił, że jest to piękno boskie ${ }^{32}$; piękno, które dla każdego odbiorcy jest rzeczą osobistą, ale jednocześnie tajemniczo złączoną z całym wszechświatem i które uobecnia pierwotną harmonię świata. Zgodnie z tradycją filozofii muzyki muzyka potrafi oddać w sposób niedościgniony zarówno ogólne, jak i szczegółowe aspekty istnienia. Wyraz emocjonalny i pozaemocjonalny, jaki przysługuje muzyce, jest nieporównywalny do czegokolwiek innego. Wilhelm Dilthey pisze, że „najwyższym dokonaniem muzyki jest (...) to, że procesy przebiegające w duszy muzykalnej w sposób mglisty, mało wyrazisty, często niepostrzeżenie dla jaźni,

29 Zob. W. James, Doświadczenia religijne, dz. cyt., s. 46.

30 Por. W. James, Doświadczenia religijne, dz. cyt., s. 47.

31 G. Steiner, Rzeczywiste obecności, op. cit., s. 118.

32 Zob. F. W. J. Schelling, Filozofia sztuki, dz. cyt., s. 7. 
znajdują mimochodem krystalicznie przejrzysty wyraz w utworze muzycznym" 33 . Piękno doznania muzyki wynika właśnie z przeżycia, twierdzi autor. Tego przeżycia nie da się objaśnić słowami, jest nieokreślone i niewyjaśnione, a jednocześnie wiąże się z głębią i intuicją doznania. „Nie istnieje także żadna określona droga do przeżycia muzyki" - pisze dalej niemiecki filozof - i ma na myśli również i to, że zachwyt nad muzyką nie jest związany z żadnym określonym elementem jej formy czy treści muzycznej ${ }^{34}$. Nie jest też związany ze sposobem odbioru muzyki, a już z pewnością nie zależy od muzycznej kompetencji odbiorcy. Innymi słowy muzyka jest równie czytelna dla każdego odbiorcy i każdy odbiorca w swoim przeżyciu muzyki może odnaleźć głębię i dostrzec niewyczerpywalność tego doznania.

Doświadczenie muzyki jest zasadniczo przeżyciem duchowym i wyrazem duchowości człowieka. Dzięki swojej bezpośredniości i głębi słuchanie muzyki staje się doświadczeniem, w którym duchowość ujawnia się najwyraźniej. Muzyka, jak uważał Dilthey, oddaje przeżycia i stany wewnętrzne podmiotu dzięki swojej niezwykłej zdolności krystalizacji emocjonalnego wyrazu ${ }^{35}$. Jeszcze wyraźniej mówił o tym Arthur Schopenhauer, określając muzykę jako „najpotężniejszą sztukę”, która może „doskonale wypełnić wrażliwego na nią ducha” ${ }^{36}$. Doświadczenie muzyki religijnej lub muzyki metamuzycznej (mistycznej) staje się doświadczeniem duchowości, a więc otwarciem na wszelkie doznania transcendujące nie tylko tu i teraz, ale także samą perspektywę podmiotową, jako punkt wyjścia - podmiot zatraca się w słuchanej muzyce.

Doświadczenie muzyki religijnej, zarówno wówczas, gdy słuchacz dostrzega ten jej wymiar, jak i wówczas, gdy jest on dla niego zatarty lub drugorzędny, wydaje się być doświadczeniem szczególnym. Należałoby zwrócić uwagę na trzy podstawowe aspekty doświadczenia muzyki religijnej: indywidualność, zaangażowanie emocjonalne oraz wsłuchiwanie się. O pierwszym z powyższych pisze James w swoim omówieniu doświadczenia religijnego, wymieniając jako podstawowy element charakterystyki doświadczenia religijnego indywidualność i zaangażowanie. Autor podkreśla emocjonalny charakter doświadczenia religijnego, pisząc o entuzjastycznym i radosnym jego wymiarze. Mówi o szczególnym „wzruszeniu, uroczystej radości” oraz „najwyższej szczęśliwości”, jaka towarzyszy osobie religij$n e j^{37}$. Uczestnik ceremonii religijnej jest zasadniczo całkowicie podporządkowany

33 W. Dilthey, Budowa świata historycznego w naukach humanistycznych, przeł. E. Paczkowska-Łagowska, Gdańsk 2004, s. 214.

34 Zob. W. Dilthey, Budowa świata historycznego w naukach humanistycznych, dz. cyt., s. 214.

35 Zob. W. Dilthey, Budowa świata historycznego w naukach humanistycznych, dz. cyt., s. 214.

36 A. Schopenhauer, W poszukiwaniu mądrości życia. Parerga i paralipomena. Drobne pisma filozoficzne, przeł. J. Garewicz, t. 2, Kęty 2004, s. 370.

37 Zob. W. James, Doświadczenia religijne, dz. cyt., s. 46-47. 
odczuwanej miłości i radości w stosunku do rzeczywistości niewidzialnej, ale jednocześnie jest to jego osobista relacja ze sferą sacrum, która wyznacza jego doświadczenie. Doświadczeniu muzyki religijnej towarzyszy również indywidualne i bardzo osobiste zaangażowanie emocjonalne, choć być może jest ono nieco innego rodzaju niż to, które dotyczy doświadczenia religijnego jako takiego. Słuchacz muzyki religijnej jest skupiony na doświadczeniu wewnętrznym, a jego przeżycia są subtelniejsze, delikatniejsze i takie również będą emocje, które temu towarzyszą. Literatura przedmiotu zwraca uwagę na skupienie na doświadczeniu i w konsekwencji na wykroczenie poza własne „ja”, poza to, co moje, poprzez nawiązanie relacji lub włączenie się we wspólnotę i przeżycie wspólnotowe. Przeżycia takie mogą opierać się na relacji potencjalnej, niepełnej lub pozbawionej wyraźnego podmiotu; jednak zawsze będą to relacje wspólnotowe oraz oparte na pominięciu, zapomnieniu, a nawet wyparciu się podmiotowego „ja”. Mówiąc o uczuciach, które towarzyszą słuchaniu muzyki religijnej, należy wziąć pod uwagę element zapośredniczenia poprzez muzykę. Nakierowanie na sacrum, jakie jest udziałem doświadczenia religijnego, w przypadku słuchania muzyki religijnej zostaje przesunięte do sfery wspólnotowego doświadczenia, w którym relacja nawiązywana jest ze wspólnotą i dopiero poprzez nią z sacrum, lub poprzez muzykę z sacrum, a nie w sposób bezpośredni, o ile mamy mówić wciąż o doświadczeniu muzyki. Stąd z jednej strony możemy mówić o powtórzeniu tego wszystkiego, co charakteryzuje doświadczenie religijne - jak indywidualność, emocjonalność i wsłuchiwanie się - lecz z drugiej należy wziąć pod uwagę, że w doświadczeniu muzyki religijnej wszystko to obecne jest w sposób mnie wyraźny i mniej gwałtowny, stąd dominującym elementem emocjonalnym będzie zawsze radość i zadowolenie, bez względu na to, jak trudna, gwałtowna i dramatyczna będzie muzyka, która jest przedmiotem doświadczenia.

Chciałabym jeszcze na moment powrócić do słuchania, jako elementu doświadczenia muzyki religijnej. Słuchanie jest oczywiście niezmiernie ważnym elementem uczestniczenia w doświadczeniu muzyki religijnej. Nie chodzi tutaj o prostą czynność słuchania, ale o całkowite zaangażowanie i wysiłek wsłuchiwania się, który ma zarazem estetyczny i religijny charakter. Ów wysiłek słuchania łączy się tutaj ze słuchaniem głosu, czyli posłuszeństwem czy też podążaniem za ${ }^{38}$. Jest to związane ze współprzeżywaniem świętości, harmonii czy powszechnej jedności, którą zakłada rzeczywistość religijna. Jak mówi James, jednym z elementów światopoglądu religijnego jest założenie o istnieniu sfery fenomenów niewidzialnych, które wpływają na fenomeny w sferze rzeczywistości widzialnej ${ }^{39}$. W doświadczeniu

38 Por. M. Heidegger, Bycie i czas, przeł. B. Baran, Warszawa 2004, s. 2009.

39 Zob. W. James, Doświadczenia religijne, dz. cyt., s. 439. 
religijnym posłuszeństwo oraz wspólnotowe współprzeżywanie stanowi często symboliczny powrót do stanu pierwotnego, tj. stanu harmonijnej jedności sprzed upadku.

W doświadczeniu muzyki religijnej słuchanie stanowi również oznakę posłuszeństwa oraz podporządkowania. To, o czym piszą mistycy, staje się udziałem odbiorcy muzyki i niejako bez specjalnego wysiłku nabiera odpowiedniego charakteru. Ten, kto słucha - wsłuchuje się - staje się jednocześnie odbiorcą i uczestnikiem. Jego doświadczenie jest drogą do Boga i słuchaniem muzyki, tutaj doświadczeniem estetycznym, w tym samym czasie. Jak zauważa James, istnieje istotny podział na religię ujmowaną poprzez osobiste, indywidualne doświadczenie oraz religię instytucjonalną. Ta pierwsza, która najbardziej interesowała filozofa, stanowi w dużej mierze przeciwieństwo tej drugiej. W religii osobistej podstawą jest „,wewnętrzne usposobienie samego człowieka, jego sumienie, samotność, bezradność i niezupełność" ${ }^{40}$. W obu przypadkach świadectwem prawdy i wartości religii jest pożytek, jaki przynosi ona jednostkom ${ }^{41}$. Doświadczenie muzyki religijnej jest być może jednym z narzędzi oraz sposobów upowszechniania religii, ale jednocześnie jako doświadczenie muzyczne stanowi ono doświadczeniem piękna i wzniosłości, które z kolei, jak przekonuje Plotyn, jest oparte na wzajemności.

Zaprawdę, nigdy nie zobaczyłoby oko słońca, gdyby samo nie było słoneczne, i nigdy też dusza nie ujrzy piękna, jeżeli sama nie będzie piękna ${ }^{42}$.

Dostrzeganie piękna, a zatem sama możliwość piękna, jest już jego świadectwem. Powtarzając za Dahlhausem, można by w nawiązaniu do wcześniejszych rozważań powiedzieć, że „wolna od uzależnień słownych i funkcjonalnych” muzyka „wznosi się” ponad” ograniczoność „skończoności ku instytucji nieskończoności”³. James zauważa ponadto, że doświadczenia religijne i mistyczne mają swój szczególny wymiar lub przekrój estetyczny ${ }^{44}$. W tym kontekście można powiedzieć również, że doświadczenia muzyki religijnej stanowią tak doskonały sposób praktykowania religii, ponieważ wzmacniają to, co stanowi istotę doświadczenia religii. Radość i wzniosłość doznania obecna w odbiorze subtelności śpiewu czy symfonicznej pełni muzyki instrumentalnej jest radością i wzniosłością przynależną każdemu

40 W. James, Odmiany doświadczenia religijnego. Studium natury ludzkiej, przeł. J. Hempel, Warszawa 2011, s. 37.

41 Zob. W. James, Doświadczenia religijne, dz. cyt., s. 439-440.

42 Plotyn, Enneady, przeł. A. Krokiewicz, ks. VI, Warszawa 2003, s. 841-842.

43 C. Dahlhaus, Idea muzyki absolutnej i inne studia, przeł. A. Buchner, Kraków 1988, s. 68.

44 Zob. W. James, Doświadczenia religijne, dz. cyt., s. 441. 
doświadczeniu religijnemu. Istnieje jednak coś, co wyróżnia doświadczenie muzyki religijnej na tle wszystkich innych typów doświadczeń religijnych, o których pisze James. Jest to kreowanie przestrzeni duchowej, rozumianej, jak była już o tym mowa, jako przestrzeń otwarcia i poszerzenia własnej świadomości. Muzyka religijna, liturgiczna oraz mistyczna daje w odbiorze wrażenie otwierania się dodatkowej przestrzeni, w której doświadczenia i emocje mają swoje miejsce. To symboliczne otwarcie i wytworzenie dodatkowej przestrzeni stanowi specyfikę doświadczenia estetycznego, jednak w ramach doświadczenia muzyki religijnej pojawia się ono ze wzmożoną siłą. Jednocześnie ma ono wymiar fizyczny, opierając się na doznaniu dotyku, fizycznego drgania, które przenika i porusza organizm. Owa fizyczna moc doznania, tj. otwarcia przestrzeni duchowej, jest niezależna od faktycznego wykorzystania przestrzeni, w której wykonywana jest muzyka. A zatem poza budynkiem kościoła lub innego miejsca konsekrowanego muzyka religijna może wciąż inicjować otwarcie przestrzeni duchowej. Zaangażowanie odbiorców, ich wysiłek wsłuchiwania się, emocjonalne zaangażowanie i wreszcie owa wewnętrzna potrzeba poszukiwania drogi do Boga, które leżą u podstaw religii, stanowią elementy wystarczające dla wzmocnienia oddziaływania muzyki.

Jednocześnie, na co zwracają uwagę różni autorzy, współczesna muzyka religijna często nie spełnia już pewnych oczywistych funkcji religijnych, jak na przykład funkcji obrzędowej, liturgicznej lub konfesyjnej. Jednym z powodów takiej zmiany jest wycofanie muzyki religijnej z przestrzeni konsekrowanej do sal koncertowych, innym może być rezygnacja kompozytora z podejmowania określonej roli religijnej ${ }^{45}$. Muzyka religijna może wciąż stawiać sobie za zadanie przemianę wewnętrzną słuchacza. Jest równie prawdopodobne, że to właśnie słuchacz, bez względu na intencje autora i jego przeświadczenie co do roli, jaką jego muzyka ma pełnić, oczekuje oraz poszukuje takiej właśnie przemiany.

\section{Tajemnica i doświadczenie autotranscendencji}

Doświadczenie estetyczne, zarówno jako doświadczenie twórcze, jak i doświadczenie odbioru dzieła, jest doświadczeniem tajemnicy, spotkaniem z tym, co nieznane, ale i wykraczaniem poza to, co znane, poszukiwaniem tego, co zakryte. W perspektywie indywidualnej doświadczenie estetyczne bywa nie tylko odkrywaniem czegoś nowego, lecz także przekraczaniem własnego ,ja”; transcendencją podmiotowości. Doświadczenie muzyki religijnej może być dodatkowo związane $\mathrm{z}$ inicjowaniem indywidualnego zaniechania; $\mathrm{z}$ samoprzekraczaniem siebie na rzecz transcendencji. James przytacza w tym kontekście przykłady rozmaitych wyrzeczeń

45 Por. S. Dąbek, Wspótczesna muzyka religijna. Uwarunkowania i aspekt duchowy, dz. cyt., s. 76. 
oraz zaniedbań, które jako rodzaj umartwienia były jednocześnie uznawane za drogę do doświadczeń pozytywnych, objawień lub sposobem religijnego życia. W doświadczeniu muzyki religijnej pojawia się możliwość porzucenia indywidualnej drogi na rzecz zatopienia się w doświadczeniu transcendencji: wykroczenia poza to, co znane, poza empirię, zmysły, intelekt, pamięć i instynkt.

\section{Wstuchiwanie się}

Być może najważniejszym elementem doświadczenia muzyki religijnej jest omawiany już element słuchania, a więc także wsłuchiwania się. Słuchanie, jak uważa Martin Heidegger, wiąże się z „podążaniem za”, „kroczeniem”. Jest ono warunkiem rozumienia, a także mówienia; aby można było mówić, trzeba [umieć] słuchać ${ }^{46}$. Zdaniem Bernarda z Clairvaux słuchanie to również jeden z elementów pokory niezbędnej w drodze dwunastu stopni pokory, które prowadzą do Boga ${ }^{47}$. Słuchanie stanowi aktywny stan, w którym podmiot znajduje się w relacji do przedmiotu, takiej, w której myśl jego na równi z narządem zmysłu podąża za dźwiękiem, tj. zarazem podporządkowuje się mu oraz za nim dąży. Jednak w przypadku muzyki religijnej wsłuchiwanie się w dźwięki, harmonię i rytmiczne wzory stanowi dodatkowo słuchanie głosu Boga. Możliwość usłyszenia Boga jest realna w każdej ceremonii, w każdej liturgii. Można nawet powiedzieć, że każdy śpiew i każde muzyczne współdziałanie jest okazją spotkania z Bogiem i okazją usłyszenia Go.

W swoich wysiłkach wyniesienia się ponad własne potrzeby i praktyczne zadania człowiek religijny znajduje zaspokojenie i ukojenie w muzyce. To, co dotyczy samego doświadczenia religijnego, w doświadczeniu muzycznym dokonuje się niezależnie od intencji albo bez względu na nie. Muzyka unosi i inicjuje oderwanie od wewnętrznej podmiotowości „ja” w sposób, jaki pozwala na nawiązanie nowej relacji. Doświadczenie muzyki jest doświadczeniem wspólnotowym i prawdziwie ekumenicznym doświadczeniem wspólnego otwarcia się na świat, jak mówią autorzy tacy, jak George Steiner czy Hans-Georg Gadamer ${ }^{48}$. Jednocześnie, aby można było mówić w tym wypadku o doświadczeniu „zapomnienia” czy o autotranscendencji, powinny być spełnione pewne warunki. Dla średniowiecznych autorów tymi warunkami były pokora i miłość ${ }^{49}$, dla autorów późniejszych byłaby to raczej

\footnotetext{
46 Por. M. Heidegger, Bycie i czas, dz. cyt., s. 209.

47 Bernard z Clairvaux, O stopniach pokory i pychy, przeł. S. Kiełtyka, Kraków 1991, s. 20-39.

48 Zob. G. Steiner, Rzeczywiste obecności, przeł. O. Kubińska, Gdańsk 1997, s. 118; H. G. Gadamer, Aktualność piękna. Sztuka jako gra, symbol i święto, przeł. K. Krzemieniowa, Warszawa 1993, s. 54.

49 Zob. Bernard z Clairvaux, O stopniach pokory i pychy, dz. cyt., s. 41.
} 
konieczność skupienia na przedmiocie doświadczenia oraz nakierowanie jakościowe. Choć skupienie stanowi podstawowy element procesu słuchania, w doświadczeniu muzyki zdarza się tak, że słuchanie przekształca się w proces marzenia lub wspominania niejako poza wolą słuchacza, który jedynie daje się ponieść w tym kierunku. W doświadczeniu religijnym przedmiotem doświadczenia może być wyłącznie sama transcendencja, ewentualnie elementy jej przejawiania się w świecie.

\section{Idealna droga: dźwięku}

Edmund Gurney w swoich badaniach filozoficznych oraz psychologicznych poszukiwał odpowiedzi na pytania o pozamaterialne doświadczenia i zakres percepcji ludzkiej. Jednocześnie w swoim opracowaniu podstawowych zasad muzyki, jej poznania i rozumienia ukazał doświadczenie dzieła muzycznego jako dostępne każdemu prostemu miłośnikowi muzyki. Te dwa kierunki badań zbiegają się właśnie na gruncie doświadczenia estetycznego muzyki. W poszukiwaniu piękna i wyjaśnieniu doświadczenia sztuki Gurney przedstawia najbardziej wnikliwy opis elementów muzyki i ich interpretacji.

\section{Zakończenie}

Odwołując się do muzyki, która bez względu na styl, wyznanie kompozytora oraz tekst liturgiczny może prowadzić do doznań wzniosłości oraz której doznaniem kieruje umysł dążący ku idei wolności i nieskończoności, można spróbować nakreślić przestrzeń doświadczenia mistycznego, jako przestrzeń duchowości wyznaczaną przez wysiłek wsłuchiwania się.

Pieśn Cherubinów Krzysztofa Pendereckiego lub Stabat mater Karola Szymanowskiego, podobnie jak Już się zmierzcha Wacława z Szamotuł, otwierają przed słuchaczem przestrzeń doświadczenia, która nie tylko wyzwala i koncentruje doznania słuchowe, pozwalając zapamiętywać i cieszyć się dźwiękiem jako takim, ale w której powstająca przestrzeń muzyczna jest przestrzenią nieskończoną; jej wzrastanie, jej rozchodzenia się wokół słuchacza staje się próbą naszkicowania tego, co niemożliwe - nieskończoności, wolności, ale wobec tego staje również zaproszeniem do dalszych poszukiwań, wykroczeniem poza to, co znane i poznane ku nieskończoności.

Doświadczenie estetyczne, jak pisze Gurney, jako doświadczenie piękna przekracza wymóg inteligencji czy racjonalności nie tylko w odniesieniu do budowy dzieła, które nie zawsze stosuje się do prostych schematów, ale również, a może przede wszystkim w odniesieniu do samego doświadczenia. Podstawą piękna, przekonuje Gurney, jest nie tyle obiektywny fakt nieskończonej doskonałości ułożenia i uporządkowania struktury dzieła podziwianego przez wysoką inteligencję, 
ile nieskończone możliwości własnego „ja”, subiektywny fakt, na którego poznanie w szczególnym doświadczeniu dusza ludzka zdaje się na moment otwieraćc ${ }^{50}$.

\begin{abstract}
Abstrakt
W poszukiwaniu fenomenologicznego ujęcia muzycznego doświadczenia religijnego autorka nawiązuje do analizy doświadczenia religijnego Williama Jamesa oraz do pism Edmunda Gurneya, a wreszcie do pracy Maxa Schelera. Sięgając do opisu doświadczeń religijnych i mistycznych, stara się naszkicować podobieństwo między doświadczeniem mistycznym, wsłuchiwaniem się a praktyką religijną opisywaną w literaturze filozoficznej. Odwołując się do muzyki, która bez względu na styl, wyznanie kompozytora oraz tekst liturgiczny, prowadzi do doświadczenia mistycznego lub religijnego, określa doświadczenie muzyki religijnej poprzez odwołanie się indywidualnego zaangażowania, emocjonalnej pełni oraz duchowej przestrzeni wyznaczanej m.in. przez wysiłek wsłuchiwania się.
\end{abstract}

Stowa kluczowe: estetyka; muzyka religijna; William James; Edmund Gurney; Max Scheler; doświadczenie muzyki; wsłuchiwanie się

\title{
Abstract \\ Freedom, Infinity and Sublimity: Spiritual Space in Experiencing Religious Music. A Phenomenological Perspective
}

In pursuing the phenomenological description of musical religious experience author refers to William James' analysis of religious experience, pointing to his ideas of the individual, emotional and above all engagement as the major elements that mark the religious experience. She refers to the aesthetic and psychological though of Edmund Gurney as well as the work of Max Scheler trying presenting a comparison between the religious and aesthetic in the context of the musical experience. Pointing to the music that may be neither functioning nor inspired by the Church, author describes the attentive and engaged

\footnotetext{
50 Zob. E. Gurney, The Psychology of Music, „Mind” 7 (1882) issue 25, s. 499, https://doi. org/10.1093/mind/os-VII.25.89 (11.06.2020).
} 
music experience that opens up the spiritual space for growing and changing oneself as the ultimate prize for the listening-in.

Keywords: aesthetics; religious music; experience of music; William James; Edmund Gurney; Max Scheler; listening-in

\section{Bibliografia}

Adorno T. W., Teoria estetyczna, przeł. K. Krzemień-Ojak, Warszawa 1993.

Adorno T. W., Minima moralia. Refleksje z poharatanego życia, przeł. M. Łukasiewicz, Kraków 1999.

Bernard z Clairvaux, O mitowaniu Boga i inne traktaty, przeł. S. Kiełtyka, Poznań 2000 (Biblioteka Christianitas, 4).

Bernard z Clairvaux, O stopniach pokory i pychy, przeł. S. Kiełtyka, Kraków 1991.

Burke E., Dociekania filozoficzne dotyczące pochodzenia naszych idei wzniostości i piękna, przeł. P. Graff, Warszawa 1968.

Czernik T., Jedno czy wiele doświadczeń religijnych w poglądach Williama Jamesa, „Perspectiva. Legnickie Studia Teologiczno-Historyczne" 10 (2011) nr 1 (18), s. 35-45.

Dahlhaus C., Idea muzyki absolutnej i inne studia, przeł. A. Buchner, Kraków 1988.

Dąbek S., Wspótczesna muzyka religijna. Uwarunkowania i aspekt duchowy, „Ethos” 19 (2006) nr 1-2, s. 76-86.

Dilthey W., Budowa świata historycznego w naukach humanistycznych, przeł. E. Paczkowska-Łagowska, Gdańsk 2004.

Gadamer H.-G., Aktualność piękna. Sztuka jako gra, symbol i święto, przeł. K. Krzemieniowa, Warszawa 1993.

Gurney E., The Power of Sound, London 1880.

Gurney E., The Psychology of Music, „Mind” 7 (1882) issue 25, s. 89-100, https://doi. org/10.1093/mind/os-VII.25.89 (11.06.2020).

Gurney E., Relations of Reason to Beauty, „Mind” 4 (1879) issue 16, s. 482-500.

Gurney E., What is Emotion?, „Mind” 9 (1884) issue 35, s. 421-426, https://doi. org/10.1093/mind/os-IX.35.421 (11.06.2020).

Heidegger M., Bycie i czas, przeł. B. Baran, Warszawa 2004.

Ingarden R., Studia z estetyki, Warszawa 1958.

James W., Doświadczenia religijne, przeł. J. Hempel, Warszawa 1958.

James W., Odmiany doświadczenia religijnego. Studium natury ludzkiej, przeł. J. Hempel, Warszawa 2011.

James W., Will to Believe and other Essays, London 1897.

James W., Z wybranych problemów filozofii, przeł. M. Filipczuk, Kraków 2006.

Kant I., Krytyka wtadzy sądzenia, przeł. J. Gałecki, Warszawa 2004. 
Kandyński W., O duchowości w sztuce, przeł. S. Fijałkowski, Łódź 1996.

Krawcowicz B., William James: Pragmatyzm i religia, Toruń 2017.

Lyotard J.-F., Po wzniostości: stanowisko estetyki, „Teksty Drugie” 1998 nr 4, s. 131-137.

Łukaszewski M., Aspekty religijne w polskiej muzyce fortepianowej XX i XXI wieku, „Aspekty Muzyki” 5 (2015), s. 27-58.

Marcel G., Dziennik metafizyczny, przeł. E. Wende, Warszawa 1987.

Perz M., Interpretacje muzycznego „sacrum” w kontekście polskiej tradycji, w: Wspótczesna polska religijna kultura muzyczna jako przedmiot badań muzykologii, pod red. B. Bartkowskiego, S. Dąbka, A. Zoły, Lublin 1992, s. 21-35.

Plotyn, Enneady, przeł. A. Krokiewicz, Warszawa 2003.

Scheler M., Pisma z antropologii filozoficznej i teorii wiedzy, przeł. S. Czerwniak, A. Węgrzecki, Warszawa 1987.

Schelling F. W. J., Filozofia sztuki, przeł. K. Krzemieniowa, Warszawa 1983.

Schmitz H., Ciatosfera, przestrzeń i uczucia, przeł. B. Andrzejewski, Poznań 2001.

Schopenhauer A., W poszukiwaniu madrości życia. Parerga i paralipomena. Drobne pisma filozoficzne, przeł. J. Garewicz, t. 2, Kęty 2004.

Steiner G., Rzeczywiste obecności, przeł. O. Kubińska, Gdańsk 1997.

Stróżewski W., Wokót piękna. Szkice z estetyki, Kraków 2002.

Tatarkiewicz W., Dzieje széśiu pojęć, Warszawa 2008.

Tomaszewski M., Muzyka w dialogu ze stowem. Próby, szkice, interpretacje, Kraków 2003.

Tomaszewski M., Interpretacja integralna dzieta muzycznego. Rekonesans, Kraków 2000.

Wspótczesna polska religijna kultura muzyczna jako przedmiot badań muzykologii, pod red. ks. B. Bartkowskiego, S. Dąbka, A. Zoły, Lublin 1992.

Zimnica-Kuzioła E., Doświadczenie religijne: perspektywa teologiczna i socjologiczna, „Collectanea Theologica" 84 (2014) nr 2, s. 61-78. 